\title{
JUURNAL.RU
}

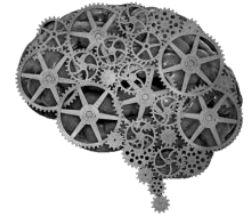

COMPANY GROUP "INTELLEKT"

\author{
Донцов Д.А. \\ Российский соииальный университет \\ Москва, Россия
}

doi: 10.18411/lj2016-3-52

\section{Системная научная методология общей психологии}

Факторы, определяющие развитие психологии как науки. 1. Потребности общества или социальный заказ; 2) логика развития самой психологической науки: то есть, - соотношение в науке теории и практики, фактов и гипотез, методологии и методов; 3) личностный фактор - гений, т.е. значимость личности в истории развития научной психологии. Общественное значение психологии - помочь людям лучше жить. Практическое значение психологии состоит в том, что психология: позволяет человеку лучше познать самого себя; помогает человеку эффективнее познавать других людей; облегчает взаимопонимание людей; способствует эффективному общению; повышает качество обучения и воспитания; облегчает правильный выбор профессии; укрепляет семью; помогает руководить собой и другими людьми и т.д.

Термин (понятие) «Психология» имеет в своей основе два греческих по происхождению слова: «психе» («псюхе») - душа, дыхание и «логос» - наука, учение. Современная психология - это наука о фактах, закономерностях и механизмах психики людей. Главные явления и феномены, изучаемые современной психологией как наукой, изучающей психику людей, и всё что связано с функционированием психики людей, отображены в таблице ниже.

Категориальный апnарат психологии. Категориальный аппарат психологии - это система понятий (категорий), отражающих предмет психологической науки, научные знания о психике людей. Категория - это 
понятие, имеющее критериальное («измерительное») значение. Категории, законы, закономерности и принципы психологии как науки являются определенными инвариантами познания, в них зафиксировано устойчивоповторяющееся, необходимое и типичное, присущее психической реальности. Овладение этими инвариантами дает психологу ключ к анализу окружающей действительности в плане вычленения еe психологической специфики. Категориальный аппарат научной психологии является содержательной логической формой познания психических явлений, формой, которая оптимально спрессовывает знания о сущности и закономерностях психической жизни людей. Каждая отрасль научной психологии (основными отраслями психологии, понимаемой в качестве науки и практики жизнедеятельности общества и человека, являются такие пять базовых отраслей психологии как: общая психология, возрастная психология, социальная психология, педагогическая психология, клиническая психология) пользуется общим для всей научной психологии категориальным аппаратом и вырабатывает свой, отраслевой аппарат категорий, отражающий особенности изучаемых явлений, условий деятельности и поведения индивидов, характеризующих именно эту отрасль, область, сферу психологии как науки и практики. Для того, чтобы глубже изучить психический мир человека, научная «Психология» выделяет такие основополагающие категории как: категория отражения, психика как категория, сознание как категория, категория деятельности, категория общения, категория образа, категория мотива, категория отночения, категория переживания, категория представления и мн.др.

Общзая психология - это базовая научно-исследовательская отрасль психологии в целом как науки, а также - информационная основа познания человека. Общзая психология - это теоретические и экспериментальные исследования, выявляющие наиболее общие психологические закономерности и методы психологии, её основные понятия. Основные понятия общей психологии характеризуют психические процессы, состояния и свойства. Таким образом, 
общая психология - это фундаментальная, основополагающая часть (область) психологии как науки и практики, изучающая те психические явления и феномены, которые психически свойственны абсолютно любому человеку. Итак, общая психология рассматривает характерные фактически для всех людей проявления психических процессов, состояний, свойств личности, а также общие характеристики человеческой деятельности и общения.

Методология общей психологии. Методология выступает как сумма методов, основанных на фактах, на выявленных научных закономерностях. Основной принцип создания методологии - нахождение закономерностей в различных явлениях и процессах. Методология - система принципов и способов организации и построения теоретической и практической деятельности. Методология также является обоснованием использования разнообразных методов. В методологию психологии, помимо разных методов психологических исследований, входят базовые проблемы психологии, основные научные подходы к исследованию психики и определяющие принципы психологии как науки, изучающей психику людей. Методология психологии - это орудие действенного познания.

Классификация методов психологического исследования. С.Л. Рубинштейн, в качестве главных психологических методов выделил наблюдение и эксперимент. Кроме того, С.Л. Рубинштейн выделил в качестве методов психологического исследования способы и приемы изучения продуктов деятельности, беседу и анкету. Вторая развёрнутая классификация методов психологического исследования, получившая распространение в отечественной психологии благодаря Б.Г. Ананьеву, - классификация болгарского психолога Г.Д. Пирьова. Г.Д. Пирьов выделил как самостоятельные методы: наблюдение: объективное - непосредственное и опосредованное, а также - субъективное; эксперимент: лабораторный, естественный и психолого-педагогический; моделирование; психологическую характеристику; вспомогательные методы: математические, графические, биохимические и др.; специфические 
методические подходы. Г.Д. Пирьов, разделил «методы» на: 1) собственно методы (наблюдение, эксперимент и пр.); 2) методические приемы; и 3) методические подходы (генетический, психофизиологический и пр.).

Б.Г. Ананьев подверг критике классификацию Г.Д. Пирьова, предложив другую классификацию методов психологии. С точки зрения Б.Г. Ананьева, методы психологического исследования являются системами операций с психологическими объектами и, вместе с тем, гносеологическими объектами психологической науки. Б.Г. Ананьев утверждал, что в классифицировании методов необходимо следовать методам системного подхода, и при этом важно определить место эмпирических методов в общей системе. По Б.Г. Ананьеву существует четыре уровня научного подхода. 1. Мировоззренческий уровень, который имеет философское содержание. 2. Общенаучный уровень. В него входит общая методология, построенная по принципу системности. 3. Уровень конкретной науки. Здесь выделяется частная или специальная методология. 4. Уровень конкретных методов исследования. Конкретный метод применяется в зависимости от поставленной в исследовании задачи. Например, для изучения ощущения используются методы психофизики, с их помощью, например, изучаются абсолютный, относительный, верхний и нижний пороги ощущений.

Б.Г. Ананьев выделил пять уровней методического содержания: 1) уровень методологического подхода; 2) уровень методики; 3) уровень методического приема; 4) уровень метода (эксперимент, наблюдение и пр.); 5) уровень организации исследования. При этом методы Б.Г. Ананьев разделил на: 1. организационные; 2. эмпирические; 3. способы обработки данных; 4. интерпретационные. К организационным методам Б.Г. Ананьев отнёс такие методы как сравнительный, лонгитюдный и комплексный. К группе эмпирических методов Б.Г. Ананьев отнёс обсервационные методы (наблюдение и самонаблюдение), эксперимент (лабораторный, полевой, естественный и др.), психодиагностические методы, метод анализа процессов и продуктов деятельности, моделирование и биографический метод. К способам обработки 
данных Б.Г. Ананьев отнёс методы математико-статистического анализа данных и методы качественного описания информационных данных. К интерпретационным методам Б.Г. Ананьев отнёс генетический метод интерпретации данных (виды - филогенетический и онтогенетический) и структурные методы интерпретации информации: классификация, типологизация и др. Важно отметить, что в данной классификации не обозначены теоретические методы психологического исследования, но, вместе с тем, выделен класс методов, «промежуточный» по статусу между эмпирическими и теоретическими, - методы представления, обработки и интерпретации данных эмпирического исследования.

Существуют и другие подходы к описанию и к классификации методов психологического исследования, но практически всегда ставится «знак тождества» между эмпирическими методами психологического исследования и психологическими методами вообще, что затрудняет определение специфики тех и других. Целесообразно, по аналогии с другими науками, выделить в психологии три класса методов: 1. Эмпирические, в которых осуществляется внешнее реальное взаимодействие субъекта и объекта исследования. 2. Теоретические, когда субъект взаимодействует с теоретической моделью объекта. 3. Интерпретация и описание, при которых субъект «внешне» взаимодействует со знаково-символическим представлением объекта (графики, таблицы, схемы, диаграммы и пр.). От теоретических методов психологии следует отличать методы умозрительной психологии, берущие начало в так называемой философской психологии. Умозрение опирается не на научные факты и эмпирические закономерности, а имеет обоснование только в личностном знании автора концепции. Умозрительный психолог, как и философ, порождает приемлемые, с его точки зрения, модели психической реальности, либо модели её конкретных элементов, составляющих: теории личности, теории общения, теории мышления, творчества, восприятия и т.д. Продуктом умозрения является учение, т.е. - некоторый целостный мысленный продукт, 
объединяющий в себе черты рационального и иррационального знания, претендующий на полноту и единственность объяснения некоторой реальности и не предусматривающий возможного опровержения при эмпирическом исследовании. Таким образом, для изучения особенностей и проявлений психики используются следующие методы: 1) всеобщие: идеалистический метод, материалистические методы; 2) общенаучные: наблюдение, эксперимент, моделирование и другие; 3) специфические: беседа, анкеты, опросы, тесты и другие.

Постскриптум. Заведующий кафедрой методологии психологии, декан факультета психологии МГУ имени М.В. Ломоносова Юрий Петрович Зинченко говорит, что для того, чтобы разобраться в вопросе о кризисе современной психологии, необходимо, обратиться к её методологическим основаниям, так как любая практика на чем-то базируется. Ю.П. Зинченко утверждает, что психологам необходимо набраться терпения и заняться исследованиями философии и методологии своей науки, ведь западные коллеги уже серьезно продвинулись в этом направлении. Зинченко Ю.П. также заявляет, что специалистам-психологам надо придти к пониманию своих основ, так как это придаст их работе системность и осмысленность. 


\section{Литература:}

1. Ананьев Б.Г. Человек как предмет познания. - СПб.: Питер, 2002.

2. Ананьев Б.Г. Избранные труды по психологии. В двух томах. - СПб.: СПбГУ, 2007.

3. Василюк Ф.Е. Методологический анализ в психологии. - М.: МГППУ; Смысл, 2003.

4. Гальперин П.Я. Психология как объективная наука. Под ред. Подольского А.И. - М.: Институт практической психологии, 1998.

5. Гальперин П.Я. Введение в психологию : Учебное пособие для вузов. - 3-е изд. - М.: Университет, 2000.

6. Гиппенрейтер Ю.Б. Введение в общую психологию : Курс лекций. - М.: Че-Ро, 2006.

7. Зинченко Ю. П. Современная методология психологии // Психология в Московском университете 1755-2005. - М.: МГУ, 2007.

8. Зинченко Ю. П. К 100-летию со дня рождения Б.Г.Ананьева. Борис Герасимович Ананьев: послание в будущее // Вестник Московского университета. Серия 14. Психология. - 2007. - №4.

9. Зинченко Ю.П. Методологические проблемы фундаментальных и прикладных психологических исследований. // Национальный психологический журнал. 2011. № 1 (5).

10. Зинченко Ю. П. Методология и метод в психологии // Ученые записки кафедры методологии психологии. - М.: МГУ, 2011.

11. Зинченко Ю.П. Типы рациональности в развитии научного психологического знания: классика, неклассика, постнеклассика // V Съезд Общероссийской общественной организации "Российское психологическое общество". Москва, 14-18 февраля 2012 года. - Т. 1. Москва, 2012.

12. Леонтьев А.Н. Лекции по общей психологии. - М., 2000.

13. Леонтьев А.Н. Деятельность. Сознание. Личность. 2-е изд., стер. - М.: Смысл, 2007. 
14. Маклаков А.Г. Общая психология : Учебник для вузов. - СПб.: Питер, 2008.

15. Немов Р.С. Общая психология. В 3-х томах. Том 1-ый. Введение в психологию. - М.: Юрайт, 2011.

16. Общая психология. Тексты: В 3 т. Изд. 2, испр. и доп. Т. 1. Введение. / Отв. ред. В.В. Петухов. Для студентов ф-тов психологии высших учебных заведений по направлению 521000 - «Психология». - М.: УМК «Психология»; Генезис, 2001.

17. Петровский А.В., Ярошевский М.Г. Психология. 5-е изд. - М.: Академия, 2006.

18. Рубинштейн С.Л. Основы общей психологии. 4-е изд. - СПб.: Питер, 2013.

19. Рыжов Б.Н. Системная психология (методология и методы психологического исследования). - М.: МГПУ, 1999.

20. Рыжов Б.Н. Теория и метод системной психологии. Системные основания психологии // Системная психология и социология, том 1, № 1, 2010; том 1, № 2, 2010; том 1, № 3, 2011.

21. Рыжов Б.Н., Донцов Д.А., Сенкевич Л.В., Консон Г.Р. Общая психология: введение в общую психологию, психология познавательных процессов, психология личности. Учебно-методическое пособие. - M.: Liteo, 2015. 